African Crop Science Journal by African Crop Science Society is licensed under a Creative Commons Attribution 3.0 Uganda License. Based on a work at www.ajol.info/ and www.bioline.org.br/cs DOI: https://dx.doi.org/10.4314/acsj.v29i1.7

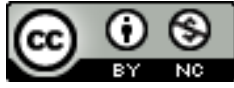

\title{
DIFFERENTIAL AND COMPARATIVE SCREENING OF COWPEA VARIETIES TO Striga gesnerioides (WILLD.) VATKE FOR RACE SPECIFIC IDENTIFICATION IN BURKINA FASO
}

\author{
P. SAWADOGO, T.J. OUEDRAOGO'1, Z. DIENI', T.B.J. BATIENO'1, N. SAWADOGO, \\ S.L. PODA ${ }^{1}$, H. ZONGO ${ }^{1}$, K. GNANKAMBARY' ${ }^{1}$ J.B.S. TIGNEGRE ${ }^{1}$ and M. SAWADOGO \\ Université Joseph KI-ZERBO, UFR/SVT, Laboratoire Biosciences / Equipe de Recherche Génétique \\ et Amélioration des plantes BP 7021, Ouagadougou 03 Burkina Faso \\ ${ }^{1}$ Institut de l'Environnement et de Recherches Agricoles (INERA) CREAF de Kamboinsé, \\ Département de Productions Végétale BP 7047, Ouagadougou 03 Burkina Faso \\ Corresponding author: pingasaw82@yahoo.fr
}

(Received 19 August 2020; accepted 14 January 2021)

\begin{abstract}
Significant efforts have been made to develop cowpea (Vigna unguiculata (L.) Walp.) varieties resistant to Striga gesnerioides in Burkina Faso. Despite these efforts, the resistant genotypes developed still express differential responses to Striga gesnerioides in different zones of the country. This suggests existence of intraspecific variability within the parasite. The objective of this study was to assess the intraspecific variability of cowpea genotypes to Striga gesnerioides infection in Burkina Faso. Ten cowpea varieties were screened over two consecutive years, under artificial infestation with 30 ecotypes of Striga seeds at Kamboinsé research station, in a screenhouse in Burkina Faso. Cowpea varieties used included Moussa local, Komsaré and KVx404-8-1, which are susceptible to all Striga ecotypes; and varieties B301, IT93K-693-2 and IT82D-849, which are free from all Striga ecotypes infestation. Cowpea varieties Tiligré, 524B, local Gorom and Niizwè had specific reactions depending on the ecotypes. The study highlights the existence of varietal specificities according to the geographical origin of Striga gesnerioides seeds. The structuring of the intraspecific diversity showed five biotypes, of which three were clearly identified as SG1, SG5 and SG Kp races; and two biotypes could not be identified. Although this study did not allow for a clear determination of the racial affiliation of the two new biotypes, it offers the possibility of developing new strategies to control Striga by focusing on the selection of resistant varieties based on regional specificities of Striga races in each agricultural zone.
\end{abstract}

Key Words: Biotypes, Striga gesnerioides, Vigna unguiculata 


\section{RESUME}

Des efforts importants ont été consentis pour développer des variétés de niébé résistantes au Striga gesnerioides. Malgré ces efforts, les génotypes résistants développés expriment des réponses différentielles au Striga gesnerioides dans différentes zones du pays. Cela suggère l'existence d'une variabilité intraspécifique au sein du parasite. D'où la nécessité d'évaluer la variabilité intraspécifique de Striga gesnerioides. Dix variétés de niébé ont été criblées sur deux années successives sous infestation artificielle avec 30 écotypes de Striga à la station de recherche de Kamboinsé. Des pots en plastique ont été utilisés comme parcelles expérimentales disposées en blocs de Fisher avec trois répétitions. Les variétés Moussa Local, Komsaré et KVx404-8-1 ont été sensibles à tous les écotypes tandis que les variétés B301, IT93K-693-2 et IT82D-849 ont été exemptes de toute infestation. Les variétés Tiligré, 524B, Gorom local et Niizwè ont eu des réactions spécifiques en fonction des écotypes. L'étude a mis en évidence l'existence de spécificités variétales selon les écotypes. La structuration de la diversité intraspécifique a montré cinq biotypes dont trois ont été clairement identifiés comme les races SG1, SG5 et SG Kp et deux n'ont pas pu être identifiés. Bien que cette étude n'ait pas permis de déterminer l'appartenance raciale des deux nouveaux biotypes, elle offre néanmoins la possibilité de développer de nouvelles stratégies de lutte contre Striga gesnerioides en se concentrant sur la sélection de variétés résistantes en fonction des spécificités régionales des races de Striga dans chaque zone agricole.

Mots Clés : Biotypes, Striga gesnerioides, Vigna unguiculata

\section{INTRODUCTION}

The practices of monoculture, the reduction of fallow time or even its abandonment, and above all, the lack of maintenance of soil fertility, has favoured the colonisation of cultivated areas by parasitic phanerogams. Thus, parasite weeds populations have gradually increased and have become serious threats to cereal and cowpea production, particularly in Sub-Saharan Africa.

Parasitic phanerogams are present, but it is in Africa that they constitute a scourge like Striga, for which four species are considered dreadful crop pests. These included Striga aspera, Striga Asiatica, Striga hermonthica and Striga gesnerioides (Parker, 2009; Csurhes et $a l ., 2013)$. Since the work of Ouédraogo (1995) and Boussim (2002) on the distribution of the different species of parasitic plants in Burkina Faso and their importance, the Striga problem has been on the increase. Striga gesnerioides, together with Striga hermonthica, are the two most ubiquitous and important Striga species causing enormous economic losses to farmers in Burkina Faso.
Striga gesnerioides, which is the subject of this study, is a parasitic plant that causes the premature dieback of cowpea plants. In susceptible cowpea varieties, Striga gesnerioides causes yield losses ranging from 30 to $100 \%$, depending on the degree of infestation (Alonge et al., 2005; Kamara et al., 2008; Omoigui et al., 2012).

There is considerable variability in the susceptibility of cowpea cultivars to this parasitic phanerogam (Tignegré et al., 2013; Ohlson and Timko, 2020). Previous work on cowpea improvement for resistance to Striga gesnerioides (Ouédraogo et al., 2001; Botanga and Timko, 2006; Li et al., 2009; Tignegré et al., 2013) has encountered great variability in the intraspecific races of the parasite. Studies conducted by Tonessia et al. (2009); Li et al. (2009) and Omoigui et al. (2012) revealed the existence of six races of Striga gesnerioides in West and Central Africa. Thus, race SG1 has been identified in Burkina Faso and Togo, race SG2 in Mali, race SG3 in Nigeria and Niger, race SG4 in Benin, race SG5 in Burkina Faso, Cameroon and Nigeria; and race SG6 in Senegal (Li et al., 2009). 
For the specific case of Burkina Faso, the present study area, three physiological races have been identified, namely SG1, SG5 and SG Kp (Ouédraogo, 2001; Tignegré et al., 2013). Significant efforts have been made to search for cowpea resistance genes to Striga gesnerioides in Burkina Faso (Tignegré, 2010; Ouedraogo et al., 2012). Nevertheless, resistant genotypes continued to have differential responses to Striga gesnerioides when moving from one agricultural region to another. This suggests the existence of greater intraspecific variability of the parasite in Burkina Faso. Thus, this study aims at a better understanding of the intraspecific variability and an efficient control of the pest by determining the racial diversity within Striga gesnerioides in Burkina Faso. The objective of this study was to determine the intraspecific diversity of Striga gesnerioides through differential screening and establish a map of spatial distribution of the different races in Burkina Faso.

\section{MATERIALS AND METHODS}

Experimental site. The experiment was conducted during two consecutive years, in June 2018 and August 2019 under artificial infestation in a greenhouse, at Kamboinsé research station in Ouagadougou, in Burkina Faso. This station is located at an altitude of about $296 \mathrm{~m}$.

Collection of seeds of Striga gesnerioides. Striga gesnerioides seeds used in the study were collected at maturity, in 30 locations across the different agro-climatic zones of Burkina Faso (Table 1). The collection was done from October to November 2017 in naturally cowpea infested fields seed samples, labelled using the site name and the GPS coordinates. Table 1 shows the names of the various localities where Striga seeds were collected.
Striga sieving technique. After collecting Striga samples, specialised fine sieves were used to separate its seeds from residues (Fig. 1). The seeds were collected in the "receiver" after passing through a mesh size of $212 \mu \mathrm{m}$. Sieved seeds were placed in glass jars and stored at room temperature (approximately 25 ${ }^{\circ} \mathrm{C}$ ) at the INERA research station in Kamboinsé in Burkina Faso. To prevent seed mixtures between locations, sieving materials were rinsed and disinfected with bleach for at least 30 minutes, before moving from one location to another.

Genetic material. The plant materials comprised of ten cowpea varieties, among which nine had known reactions (Table 2) to the six races of Striga gesnerioides identified in West Africa. In addition, 30 ecotypes of Striga gesnerioides seeds from different geographical origin were used to screen the cowpea varieties for levels of resistance.

Experimental design and cultural practices. The experimental design was a randomised complete block design, with three replications. The experiment was conducted under artificial infestation in screenhouses, using three litres plastic pots. Each pot was filled to the threequarters of its volume with a sterilised soil. The sterilisation aimed to destroy any seeds of weeds, mainly Striga gesnerioides seeds, which could be in the soil.

The soil consisted of a mixture of clay and sand at the proportions of 30\% clay and 70\% sand. Then the pots were artificially infested with $0.6 \mathrm{~g}$ of Striga gesnerioides seeds, corresponding to the minimum quantity of about 10,000 seeds of the parasite.

Striga gesnerioides seeds were preconditioned to break their dormancy by watering the infested pots for 14 days before sowing cowpea, as suggested by Husson et al. (2008). Two cowpea seeds were sown per pot and 15 days later, seedlings were thinned to one per pot. 
TABLE 1. Characteristics of the locations from which the Striga gesnerioides seeds were collected in Burkina Faso

\begin{tabular}{|c|c|c|c|c|c|}
\hline \multirow{2}{*}{$\begin{array}{l}\text { Agro-climatic zones } \\
\text { North-Sahelian }\end{array}$} & \multirow{2}{*}{$\begin{array}{l}\text { Province } \\
\text { Soum }\end{array}$} & \multirow{2}{*}{$\begin{array}{l}\text { Commune } \\
\text { Pobé-Mengao }\end{array}$} & \multirow{2}{*}{$\begin{array}{c}\begin{array}{c}\text { Ecotype } \\
\text { code }\end{array} \\
\text { SPM }\end{array}$} & \multicolumn{2}{|c|}{ GPS coordinates } \\
\hline & & & & $13^{\circ} 54^{\prime} 17^{\prime} \mathrm{N}$ & $001^{\circ} 44^{\prime} 79^{\prime} \mathrm{W}$ \\
\hline North-Sahelian & Séno & Dori & SDN & $14^{\circ} 04^{\prime} 65^{\prime} \mathrm{N}$ & $000^{\circ} 03^{\prime} 23^{\prime} \mathrm{W}$ \\
\hline North-Sahelian & Séno & Bani & SB & $13^{\circ} 42^{\prime} 15^{\prime} \mathrm{N}$ & $000^{\circ} 10^{\prime} 59^{\prime} \mathrm{W}$ \\
\hline South-Sahelian & Loroum & Titao & LO & $13^{\circ} 40^{\prime} 98^{\prime} \mathrm{N}$ & $001^{\circ} 58^{\prime} 69^{\prime} \mathrm{W}$ \\
\hline South-Sahelian & Yatenga & Séguenega & YS & $13^{\circ} 28^{\prime} 49^{\prime} \mathrm{N}$ & $001^{\circ} 58^{\prime} 72 \mathrm{~W}^{\prime}$ \\
\hline South-Sahelian & Namentenga & Dargo & NDY & $12^{\circ} 36^{\prime} 05^{\prime} \mathrm{N}$ & $000^{\circ} 15^{\prime} 19^{\prime} \mathrm{W}$ \\
\hline South-Sahelian & Sanmatenga & Pibaoré & SPO & $12^{\circ} 57^{\circ} 72^{\prime} \mathrm{N}$ & $000^{\circ} 54^{\prime} 65^{\prime} \mathrm{W}$ \\
\hline South-Sahelian & Sourou & Lankoue & SL & $13^{\circ} 12^{\prime} 71^{\prime} \mathrm{N}$ & $002^{\circ} 35^{\prime} 62^{\prime} \mathrm{W}$ \\
\hline South-Sahelian & Sourou & Toéni & STD & $13^{\circ} 20^{\prime} 69^{\prime} \mathrm{N}$ & $003^{\circ} 12^{\prime} 34^{\prime} \mathrm{W}$ \\
\hline North-Soudanian & Fada N'Gourma & Boulontou & FFB & $12^{\circ} 08^{\prime} 85^{\prime} \mathrm{N}$ & $000^{\circ} 01^{\prime} 09^{\prime} \mathrm{W}$ \\
\hline North-Soudanian & Fada N'Gourma & Kouaré & FK & $12^{\circ} 00^{\prime} 77^{\prime} \mathrm{N}$ & $001^{\circ} 19^{\prime} 59^{\prime} \mathrm{W}$ \\
\hline North-Soudanian & Fada N'Gourma & Diapangou & FD & $12^{\circ} 06^{\prime} 60^{\prime} \mathrm{N}$ & $000^{\circ} 09^{\prime} 129 \mathrm{~W}$ \\
\hline North-Soudanian & Boulgou & Tenkodogo & $\mathrm{BTe}$ & $11^{\circ} 34^{\prime} 3^{\prime} \mathrm{N}$ & $000^{\circ} 23^{\prime} 44^{\prime} \mathrm{W}$ \\
\hline North-Soudanian & Kouritenga & Baskouré & KKB & $12^{\circ} 13^{\prime} 21^{\prime} \mathrm{N}$ & $000^{\circ} 19^{\prime} 15^{\prime} \mathrm{W}$ \\
\hline North-Soudanian & Kouritenga & Sapaga & KS & $12^{\circ} 11^{\prime} 57^{\prime} \mathrm{N}$ & $000^{\circ} 28^{\prime} 04^{\prime} \mathrm{W}$ \\
\hline North-Soudanian & Ganzourgou & Zam & GZR & $12^{\circ} 18^{\prime} 05^{\prime} \mathrm{N}$ & $000^{\circ} 54^{\prime} 55^{\prime} \mathrm{W}$ \\
\hline North-Soudanian & Bazèga & Ipélcé & BI & $11^{\circ} 52^{\prime} 32^{\prime} \mathrm{N}$ & $001^{\circ} 33^{\prime} 31^{\prime} \mathrm{W}$ \\
\hline North-Soudanian & Bazèga & Toécé & BTo & $11^{\circ} 48^{\prime} 14^{\prime} \mathrm{N}$ & $001^{\circ} 15^{\prime} 55^{\prime} \mathrm{W}$ \\
\hline North-Soudanian & Oubritenga & Manega & $\mathrm{OM}$ & $12^{\circ} 49^{\prime} 12^{\prime} \mathrm{N}$ & $01^{\circ} 29^{\prime} 61^{\prime} \mathrm{W}$ \\
\hline North-Soudanian & Oubritenga & Zitenga & $\mathrm{OZN}$ & $12^{\circ} 40^{\prime} 65^{\prime} \mathrm{N}$ & $001^{\circ} 19^{\prime} 42^{\prime} \mathrm{W}$ \\
\hline North-Soudanian & Kadiogo & Tintilou & KT & $12^{\circ} 12^{\prime} 49^{\prime} \mathrm{N}$ & $001^{\circ} 48^{\prime} 84^{\prime} \mathrm{W}$ \\
\hline North-Soudanian & Kadiogo & Kamboinsé & $\mathrm{Kb}$ & $12^{\circ} 26^{\prime} 59^{\prime} \mathrm{N}$ & $001^{\circ} 33^{\prime} 08 \mathrm{~W}$ \\
\hline North-Soudanian & Boulkiemdé & Saria & BSG & $12^{\circ} 14^{\prime} 86^{\prime} \mathrm{N}$ & $002^{\circ} 08^{\prime} 32^{\prime} \mathrm{W}$ \\
\hline North-Soudanian & Nayala & Toma & NTP & $12^{\circ} 46^{\prime} 28^{\prime} \mathrm{N}$ & $002^{\circ} 42^{\prime} 99^{\prime} \mathrm{W}$ \\
\hline South-Soudanian & Nahouri & Po & NPO & $11^{\circ} 13^{\prime} 48^{\prime} \mathrm{N}$ & $001^{\circ} 17^{\prime} 31^{\prime} \mathrm{W}$ \\
\hline South-Soudanian & Zoundwéogo & Nobéré & $\mathrm{ZN}$ & $11^{\circ} 31^{\prime} 72^{\prime} \mathrm{N}$ & $001^{\circ} 11^{\prime} 70^{\prime} \mathrm{W}$ \\
\hline South-Soudanian & Ziro & Sapouy & ZSF & $11^{\circ} 25^{\prime} 61^{\prime} \mathrm{N}$ & $001^{\circ} 36^{\prime} 33^{\prime} \mathrm{W}$ \\
\hline South-Soudanian & Sanguié & Tita & SPT & $11^{\circ} 57^{\prime} 78^{\prime} \mathrm{N}$ & $002^{\circ} 22^{\prime} 81^{\prime} \mathrm{W}$ \\
\hline South-Soudanian & Balé & Poura & BPB & $11^{\circ} 46^{\prime} 91^{\prime} \mathrm{N}$ & $002^{\circ} 45^{\prime} 38^{\prime} \mathrm{W}$ \\
\hline South-Soudanian & Houet & Bama & $\mathrm{HB}$ & $11^{\circ} 25^{\prime} 21^{\prime} \mathrm{N}$ & $004^{\circ} 26^{\prime} 96^{\prime} \mathrm{W}$ \\
\hline
\end{tabular}

The experimental design was a randomised complete block design, with three replications. Supplementary watering was done whenever necessary. To reduce fungal attacks, a fungicide treatment (Apronstar) was applied at the $3^{\text {rd }}$ week after sowing at a rate of $5 \mathrm{~g} \mathrm{l}^{-1}$.

Data collection. Observations were made on three parameters, namely number of days to first emergence of Striga shoot, Striga shoot emergence and severity of Striga attack. For the number of days to first emergence of Striga shoot (DES), observations were recorded daily from the $30^{\text {th }}$ day after planting up to $75^{\text {th }}$ days after planting. As for number of Striga shoots emerged per pot, observations were made at 45 (NSSP45), 60 (NSSP60) and 75 (NSSP75) days after planting. With respect to severity of Striga attack, assessment was done at 45; 60 and 75 days after planting (SEV45), (SEV60) and (SEV75), respectively, using a scale ranging from 1 to 5 (Singh and 


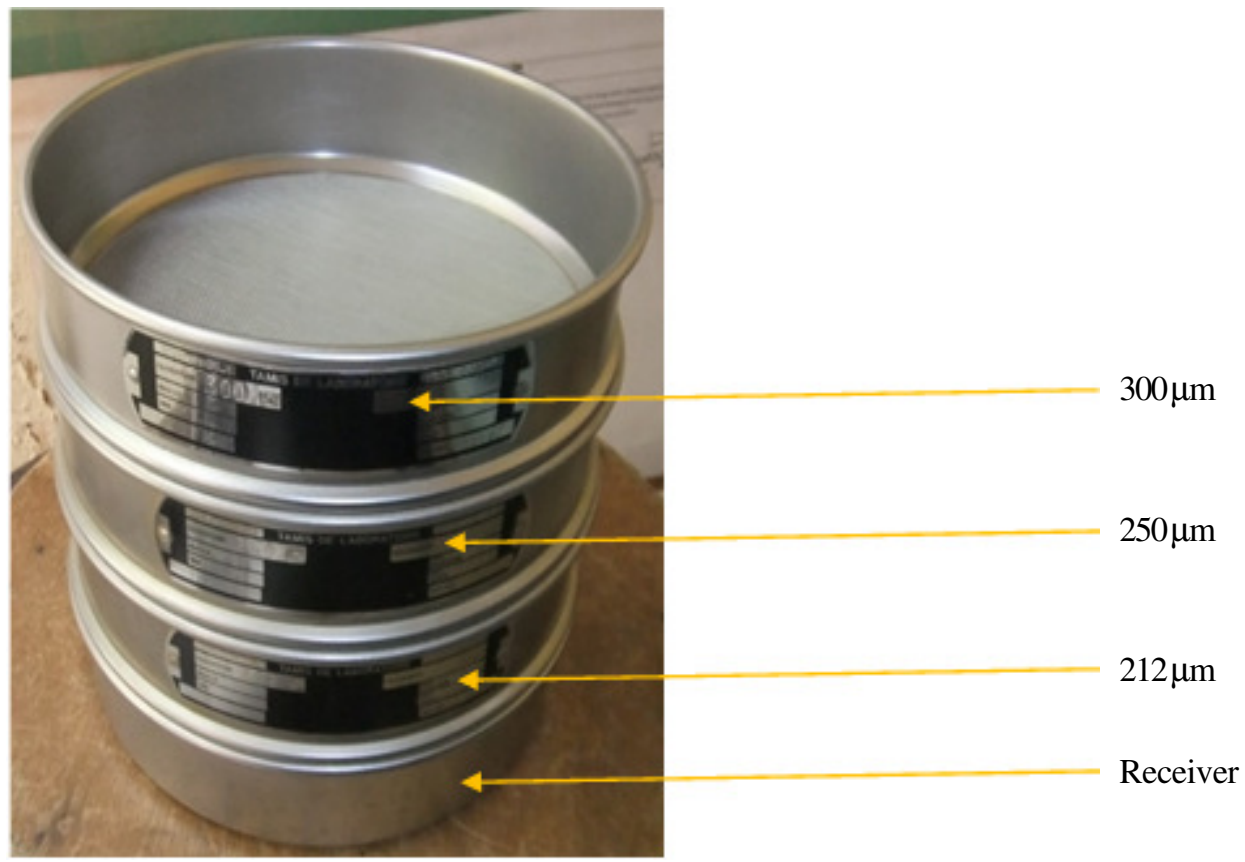

Figure 1. Striga gesnerioides sieving material used in the study.

Emechebe, 1997). Each level describing the general condition of the plant and its foliage as follows:

(i) individuals that have not emerged any Striga plants (total absence of Striga);

(ii) individual having induced the germination and emergence of Striga without allowing its development (presence of a few feet of Striga that can die before the end of their life cycle);

(iii) presence of several Striga plants without visible damage to cowpea plants;

(iv) presence of several Striga plants with slight damage to cowpea plants (leaf discolouration, yellowing, stunting, etc.); and

(v) presence of a large population of Striga with severe attack followed by death of the cowpea plant.

In addition, the presence of Striga was rated 1 and the absence 0 . This rating was used to discriminate Striga ecotypes based on the differential responses of cowpea varieties according to the geographical origin of Striga gesnerioides seeds. Plants that showed Striga emergence and development were considered susceptible. Plants free of Striga were classified as resistant.

Data analysis. Analysis of variances (ANOVA) and correlation analysis were performed on $\mathrm{R}$ software (Rstudio version1.1.463) for ecotype and ecotype by variety interactions. Means were separated using Student Newman Keuls test, at 5\% significance level, whenever the ANOVA test was significant. Cluster analysis was carried out with the presence/absence parameter of Striga on cowpea, using the Ward's aggregation method.

\section{RESULTS}

Responses of cowpea varieties. The response of cowpea varieties to Striga gesnerioides was highly significant for different variables, except for the date of 
TABLE 2. Characteristics of the cowpea varieties tested in the Striga study during the experiment

\begin{tabular}{|c|c|c|c|c|c|c|c|c|c|c|c|}
\hline \multirow[t]{2}{*}{ Variety } & \multirow[t]{2}{*}{ Origin } & \multirow{2}{*}{$\begin{array}{l}\text { Seed } \\
\text { colour }\end{array}$} & \multirow{2}{*}{$\begin{array}{c}\text { Maturity } \\
\text { cycle }\end{array}$} & \multicolumn{7}{|c|}{ Races of Striga gesnerioides } & \multirow[t]{2}{*}{ References } \\
\hline & & & & SG1 & $\mathrm{SG} 2$ & SG3 & SG4 & SG5 & SG6 & $\overline{\mathrm{SG} \mathrm{Kp}}$ & \\
\hline \multicolumn{12}{|c|}{ Susceptible varieties to Striga gesnerioides } \\
\hline Moussa Local & Burkina Faso & White & 85 & $\mathrm{~S}$ & S & S & $\mathrm{S}$ & $\mathrm{S}$ & $S$ & $\mathrm{~S}$ & Tignegré (2010) \\
\hline Komsaré & Burkina Faso & White & 70 & $\mathrm{~S}$ & $S$ & $\mathrm{~S}$ & $\mathrm{~S}$ & $\mathrm{~S}$ & S & $\mathrm{S}$ & Tignegré (2010) \\
\hline KVx404-8-1 & Burkina Faso & White & 65 & $\mathrm{~S}$ & S & $\mathrm{S}$ & S & $\mathrm{S}$ & S & $\mathrm{S}$ & Tignegré (2010) \\
\hline \multicolumn{12}{|c|}{ Varieties with differential reaction to Striga gesnerioides } \\
\hline B301 & Botswana & brown & 70 & $\mathrm{R}$ & $\mathrm{R}$ & $\mathrm{R}$ & $\mathrm{R}$ & $\mathrm{R}$ & $\mathrm{R}$ & $\mathrm{R}$ & Lane et al. (1996); Li et al. (2009) \\
\hline IT82D-849 & Nigeria & Red & 70 & $\mathrm{R}$ & $\mathrm{R}$ & $\mathrm{R}$ & $?$ & $\mathrm{R}$ & $\mathrm{R}$ & $\mathrm{R}$ & Li et al. (2009); Tignegré, (2010) \\
\hline IT93K693-2 & Nigeria & Red & 70 & $\mathrm{R}$ & $\mathrm{R}$ & $\mathrm{R}$ & $\mathrm{R}$ & $\mathrm{R}$ & $\mathrm{R}$ & $\mathrm{R}$ & Salifou et al. (2017); Tignegré et al. (2013) \\
\hline Tiligré & Burkina Faso & White & 70 & $\mathrm{R}$ & $?$ & $?$ & $?$ & $?$ & $?$ & $\mathrm{~S}$ & Tignegré et al. (2013) \\
\hline $524 \mathrm{~B}$ & Burkina Faso & White & 70 & $\mathrm{~S}$ & $\dot{S}$ & $\mathrm{R}$ & S & S & $\dot{S}$ & $\mathrm{R}$ & Li et al. (2009); Tignegré et al. (2013) \\
\hline Gorom Local & Burkina Faso & Red & 70 & $\mathrm{R}$ & $\mathrm{R}$ & $\mathrm{S}$ & $\mathrm{R}$ & $\mathrm{S}$ & $\mathrm{R}$ & $\mathrm{S}$ & Li et al. (2009); Tignegré et al. (2013) \\
\hline Niizwè & IITA & White & 65 & $\mathrm{R}$ & $\mathrm{S}$ & $\mathrm{R}$ & $\mathrm{S}$ & $\mathrm{R}$ & $S$ & $\mathrm{R}$ & Tignegré et al. (2013) \\
\hline
\end{tabular}


emergence (DES) (Table 3). The number of Striga plants emerged per cowpea variety was 0 for resistant varieties and ranged from 0.01 for the less susceptible varieties, to 11.87 for the most susceptible varieties. B301, IT82D849 and IT93K693-2 showed a good level of resistance to Striga, since no Striga emergence was observed on these varieties.

Varieties 524B, Tiligré, Gorom Local and Niizwè, however, had different reactions with a relatively low infestation rate (Table 3 ). The number of Striga shoots emerged on these varieties ranged from 0.01 for Niizwè, to 3.07 for variety 524B at 75 days after planting. The varieties which recorded the largest numbers of Striga plants on the $75^{\text {th }}$ day after planting were KVx404-8-1 with 3.46; Moussa local with 8.39 and Komsaré with 11.87 .

The number of Striga shoots emerged and the severity of attacks were significant for both cowpea varieties and the ecotypes of Striga (Table 4). The results also showed highly significant differences of genotype by environment interactions, between cowpea varieties and Striga ecotypes.
Reaction of cowpea varieties to ecotypes of Striga gesnerioides. Results of reaction of cowpea varieties to the different ecotypes of Striga gesnerioides are presented in Table 5. Based on these results, some varieties were either susceptible or resistant to all the ecotypes of Striga tested. However, four varieties (Tiligré, Niizwè, 524B, Gorom Local) revealed different response to the Striga ecotypes. Varieties KVx404-8-1, Moussa Local and Komsaré confirmed their susceptibility by inducing germination of Striga seeds, regardless of their provenance. In contrast, varieties B301, IT82D-849 and IT93K-693-2 showed very good resistance to all sources of Striga gesnerioides seeds tested, as no Striga shoots were observed on them. Varieties Tiligré, Niizwè, 524B and Gorom Local reacted differently to Striga infestation depending on Striga ecotypes (Table 5). Thus, variety Tiligré showed total resistance to ecotypes from Titao, Toéni and Séguénéga across the two cropping seasons. Variety 524B showed resistance to Striga ecotypes from Poura, Saria and Bama. Landrace Gorom Local proved

TABLE 3. Striga resistance parameters for the tested cowpea varieties across environment and years

\begin{tabular}{llllllll}
\hline Variables & DES & NSSP45 & NSSP60 & NSSP75 & SEV45 & SEV60 & SEV75 \\
\hline Moussa local & 59,53 & $0,47 \mathrm{abc}$ & $2,68 \mathrm{~b}$ & $8,39 \mathrm{~b}$ & $1,18 \mathrm{ab}$ & $1,67 \mathrm{~b}$ & $2,89 \mathrm{~b}$ \\
Tiligré & 58,71 & $0,16 \mathrm{abc}$ & $0,79 \mathrm{~cd}$ & $1,75 \mathrm{~cd}$ & $1,06 \mathrm{~b}$ & $1,21 \mathrm{c}$ & $1,45 \mathrm{~d}$ \\
Komsaré & 56,93 & $0,73 \mathrm{a}$ & $4,46 \mathrm{a}$ & $11,87 \mathrm{a}$ & $1,25 \mathrm{a}$ & $2,19 \mathrm{a}$ & $3,15 \mathrm{a}$ \\
KVx404-8-1 & 57,94 & $0,61 \mathrm{ab}$ & $0,93 \mathrm{~cd}$ & $3,46 \mathrm{c}$ & $1,36 \mathrm{a}$ & $1,52 \mathrm{~b}$ & $2,25 \mathrm{c}$ \\
Niizwè & 61,50 & $0 \mathrm{c}$ & $0,01 \mathrm{~d}$ & $0,01 \mathrm{~d}$ & $1 \mathrm{~b}$ & $1,02 \mathrm{c}$ & $1,02 \mathrm{e}$ \\
Gorom local & 51 & $0,04 \mathrm{bc}$ & $0,11 \mathrm{~d}$ & $0,11 \mathrm{~d}$ & $1,06 \mathrm{~b}$ & $1,10 \mathrm{c}$ & $1,15 \mathrm{e}$ \\
524B & 53,47 & $0,68 \mathrm{a}$ & $1,56 \mathrm{c}$ & $3,07 \mathrm{c}$ & $1,37 \mathrm{a}$ & $1,64 \mathrm{~b}$ & $2,10 \mathrm{c}$ \\
B301 & - & $0 \mathrm{c}$ & $0 \mathrm{~d}$ & $0 \mathrm{~d}$ & $1 \mathrm{~b}$ & $1 \mathrm{c}$ & $1 \mathrm{e}$ \\
IT93K693-2 & - & $0 \mathrm{c}$ & $0 \mathrm{~d}$ & $0 \mathrm{~d}$ & $1 \mathrm{~b}$ & $1 \mathrm{c}$ & $1 \mathrm{e}$ \\
IT82D-849 & - & $0 \mathrm{c}$ & $0 \mathrm{~d}$ & $0 \mathrm{~d}$ & $1 \mathrm{~b}$ & $1 \mathrm{c}$ & $1 \mathrm{e}$ \\
& & & & & & & $8.06 * * *$ \\
F-Value & 1.55 & $4.06 * * *$ & $15 * * *$ & $35.26 * * *$ & $27.4 * * *$ & $83.7 * * *$ \\
Pr>F & $0.163 \mathrm{~ns}$ & $<0,0001$ & $<0,0001$ & $<0,0001$ & $<0,0001$ & $<0,0001$ & $<0,0001$ \\
\hline
\end{tabular}

DES = Date of emergence of the first Striga plant in each pot in number of days after sowing; NSSP45, NSSP60 and NSSP75 = number of Striga plants emerged in each pot at 45; 60 and 75 days after sowing; SEV45, SEV60 and SEV75 = severity of Striga attacks at 45; 60 and 75 days after sowing 
TABLE 4. Mean square and sum of mean squares of the number of Striga plants emerged per pot and the severity score assigned to the effects of Striga on cowpea

\begin{tabular}{|c|c|c|c|c|c|}
\hline \multirow{2}{*}{$\begin{array}{l}\text { Sum square } \\
\text { Source }\end{array}$} & \multirow[t]{2}{*}{ df } & \multicolumn{4}{|c|}{ Mean square } \\
\hline & & NSSP & SEV & NSSP & SEV \\
\hline Replication & 2 & 111 & 1.33 & 55.27 & 0.663 \\
\hline Variety & 10 & $24445 * * *$ & $802.54 * * *$ & $2444.47 * * *$ & $80.254 * * *$ \\
\hline Ecotype & 31 & $5618 * * *$ & $79.33 * * *$ & $181.23 * * *$ & $2.559 * * *$ \\
\hline Variety*Ecotype & 300 & $20638 * * *$ & $332.93 * * *$ & $68.79 * * *$ & $1.106^{* * * *}$ \\
\hline Year & 1 & 196 & $3.36^{*}$ & 196.1 & $3.359 *$ \\
\hline Year*ecotype & 21 & $2299 * *$ & 20.91 & $109.50 * *$ & 0.951 \\
\hline Year* variety & 8 & 336 & $19.05 * * *$ & 42.06 & $2.381 * * *$ \\
\hline Year*Variety*Ecotype & 167 & $13794 * * *$ & $152.89 *$ & $82.60 * * *$ & $0.869 *$ \\
\hline Error & 1023 & 52516 & 768.28 & 51.34 & 0.719 \\
\hline
\end{tabular}

NSSP = number of Striga plants emerged in each pot; SEV: severity of Striga attacks

resistant to most ecotypes, except for the ecotypes of Tenkodogo, Boulontou, Po, Bani, Dori and Nobere. Variety Niizwè was susceptible to only three ecotypes of Striga, among which two (Tenkodogo and Boulontou) were common to the other differential varieties.

Striga ecotypes by number of Striga shoots emerged and the severity of attack. The analysis of variance showed that the number of Striga shoots emerged and the severity score varied according to the origin of Striga gesnerioides seeds (Table 6).

\section{Structure analysis of Striga gesnerioides} diversity. Cluster analysis using data on presence (1) or absence (0) yielded five physiological groups of Striga (Fig. 2). Group I was made up of 17 Striga ecotypes. Observation of the results in Table 7 shows that among the four different varieties, Gorom local and Niizwè were resistant to ecotypes in group I; while varieties Tiligré and 524B were susceptible to ecotypes in group I. Group II consisted of three ecotypes to which variety Tiligré was susceptible; whereas varieties 524B, Niizwè and Gorom Local were resistant to these ecotypes. Group III was also composed of three ecotypes. All the four different varieties showed susceptibility to the entire ecotypes of this group.

Group IV consisted of three ecotypes, to which only variety 524B was susceptible (Fig. 2). Group V was composed of four ecotypes to which only the variety Niizwè showed resistance. Table 8 presents the recap of the five biotypes of Striga gesnerioides derived from the cluster analysis. This grouping gave a general overview of the spatial distribution of the different biotypes of Striga gesnerioides in Burkina Faso.

Determination of races of Striga gesnerioides. A comparison of the ecotypes of Striga gesnerioides characterised in the present study, with the races already described in Burkina Faso, shows that ecotypes in group I, III and V can be identified as races SG1, SG5 and SG Kp, respectively. The ecotype in group II and IV differed from the three known races. The ecotypes of group II preferentially parasitise variety Tiligré. In addition, group III differs from the other four groups because the ecotypes in this group can parasitise all the four varieties, which is not the case for the other groups. 
TABLE 5. Number of Striga shoots emerged by cowpea variety and per year.

\begin{tabular}{|c|c|c|c|c|c|c|c|c|c|c|c|c|c|c|c|c|c|c|c|c|}
\hline \multirow[t]{2}{*}{ Variety } & \multicolumn{2}{|c|}{$524 \mathrm{~B}$} & \multicolumn{2}{|c|}{ Gorom local } & \multicolumn{2}{|c|}{ Komsaré } & \multicolumn{2}{|c|}{ KVX404-8-1 } & \multicolumn{2}{|c|}{ Moussa local } & \multicolumn{2}{|c|}{ Niizwè } & \multicolumn{2}{|c|}{ Tiligré } & \multicolumn{2}{|c|}{ IT82D-849 } & \multicolumn{2}{|c|}{ IT93K-693-2 } & \multicolumn{2}{|c|}{ B301 } \\
\hline & 2018 & 2019 & 2018 & 2019 & 2018 & 2019 & 2018 & 2019 & 2018 & 2019 & 2018 & 2019 & 2018 & 2019 & 2018 & 2019 & 2018 & 2019 & 2018 & 2019 \\
\hline Ecotypes & S PSP & PSP & PSP & PSP & PSP & PSP & PSP & PSP & PSP & PSP & PSP & PSP & PSP & PSP & PSP & PSP & PSP & PSP & PSP & PSP \\
\hline BI Ipélcé & $1 b$ & nt & $0 \mathrm{~b}$ & nt & $5.33 \mathrm{~b}$ & nt & $8.0 \mathrm{~b}$ & nt & $23.0 \mathrm{a}$ & nt & $0 \mathrm{~b}$ & nt & $2.33 \mathrm{~b}$ & nt & $0 \mathrm{~b}$ & nt & $0 \mathrm{~b}$ & nt & $0 \mathrm{~b}$ & $\mathrm{nt}$ \\
\hline BPB & $0 \mathrm{a}$ & nt & $0 \mathrm{a}$ & nt & 13 & nt & $2.66 \mathrm{a}$ & nt & $6.66 \mathrm{a}$ & nt & $0 \mathrm{a}$ & nt & $1.66 \mathrm{a}$ & nt & $0 \mathrm{a}$ & nt & $0 \mathrm{a}$ & $\mathrm{nt}$ & $0 \mathrm{a}$ & $\mathrm{nt}$ \\
\hline BSG & $2.33 b$ & nt & $0 \mathrm{~b}$ & nt & $26.00 \mathrm{a}$ & nt & $6.00 \mathrm{~b}$ & $\mathrm{nt}$ & $22.33 \mathrm{a}$ & nt & $0 \mathrm{~b}$ & nt & $0.33 b$ & nt & $0 \mathrm{~b}$ & nt & $0 \mathrm{~b}$ & nt & $0 \mathrm{~b}$ & nt \\
\hline $\mathrm{BTe}$ & $22,00 \mathrm{a}$ & $1,33 \mathrm{~b}$ & $2,66 \mathrm{a}$ & $7,33 \mathrm{~b}$ & $15,00 \mathrm{a}$ & $23 a$ & $9,66 \mathrm{a}$ & $11,66 \mathrm{~b}$ & $14,33 a$ & $10 \mathrm{~b}$ & $0,33 a$ & $4,66 \mathrm{~b}$ & $23,66 a$ & $0,66 \mathrm{~b}$ & $0 \mathrm{~b}$ & $0 \mathrm{~b}$ & $0 \mathrm{~b}$ & $0 \mathrm{~b}$ & $0 \mathrm{~b}$ & $0 \mathrm{~b}$ \\
\hline BTo & $0.66 \mathrm{~b}$ & nt & $0 \mathrm{~b}$ & nt & $14.00 \mathrm{a}$ & $\mathrm{nt}$ & $4.00 \mathrm{~b}$ & $\mathrm{nt}$ & $0.66 \mathrm{~b}$ & nt & $0 \mathrm{~b}$ & $\mathrm{nt}$ & $1.33 \mathrm{~b}$ & nt & $0 \mathrm{~b}$ & nt & $0 \mathrm{~b}$ & nt & $0 \mathrm{~b}$ & nt \\
\hline FD & $0.33 \mathrm{~b}$ & $22,5 \mathrm{a}$ & $0 \mathrm{~b}$ & $0 \mathrm{~b}$ & $25.66 \mathrm{a}$ & $6,66 \mathrm{~b}$ & $1.00 \mathrm{~b}$ & $13,66 a b$ & $5.66 \mathrm{~b}$ & $8 b$ & $0 \mathrm{~b}$ & $0 \mathrm{~b}$ & $0 \mathrm{~b}$ & $7,33 \mathrm{~b}$ & Oa & $0 \mathrm{~b}$ & $0 \mathrm{a}$ & $0 \mathrm{~b}$ & $0 \mathrm{a}$ & $0 \mathrm{~b}$ \\
\hline FFB & $5.66 \mathrm{a}$ & $13 \mathrm{ab}$ & $0 \mathrm{a}$ & nt & $4.00 \mathrm{a}$ & $14 \mathrm{ab}$ & $0 \mathrm{a}$ & $2,66 \mathrm{~b}$ & $2.66 \mathrm{a}$ & $28 \mathrm{a}$ & $0 \mathrm{a}$ & $0 \mathrm{~b}$ & $0 \mathrm{a}$ & $5 b$ & $0 \mathrm{~b}$ & $0 \mathrm{~b}$ & $0 \mathrm{~b}$ & $0 \mathrm{~b}$ & $0 \mathrm{~b}$ & $0 \mathrm{~b}$ \\
\hline FK & $0.33 b$ & $8,33 \mathrm{a}$ & $0 \mathrm{~b}$ & $0 \mathrm{~b}$ & $15.00 \mathrm{a}$ & $18 \mathrm{a}$ & $2.33 \mathrm{ab}$ & $12 \mathrm{a}$ & $10.00 \mathrm{ab}$ & $\mathrm{nt}$ & $0 \mathrm{~b}$ & $2 \mathrm{a}$ & $0 \mathrm{~b}$ & 4,66a & $0 \mathrm{~b}$ & $0 \mathrm{~b}$ & $0 \mathrm{~b}$ & $0 \mathrm{~b}$ & $0 \mathrm{~b}$ & $0 \mathrm{~b}$ \\
\hline GZR & $12.33 \mathrm{~b}$ & $\mathrm{nt}$ & $0 \mathrm{~b}$ & nt & $37.66 \mathrm{a}$ & nt & $0.66 \mathrm{~b}$ & $\mathrm{nt}$ & $13.33 \mathrm{~b}$ & nt & $0 \mathrm{~b}$ & nt & $4.66 \mathrm{~b}$ & nt & $0 \mathrm{a}$ & nt & $0 \mathrm{a}$ & nt & $0 \mathrm{a}$ & nt \\
\hline $\mathrm{HB}$ & $0 \mathrm{a}$ & $0 c$ & $0 \mathrm{a}$ & $0 c$ & $8,00 \mathrm{a}$ & $12 \mathrm{c}$ & $4,00 \mathrm{a}$ & $82 a$ & $10,33 \mathrm{a}$ & $69 \mathrm{~b}$ & $0 \mathrm{a}$ & $0 \mathrm{c}$ & $0 \mathrm{a}$ & $13,5 \mathrm{c}$ & $0 \mathrm{a}$ & $0 \mathrm{c}$ & $0 \mathrm{a}$ & $0 \mathrm{c}$ & $0 \mathrm{a}$ & nt \\
\hline $\mathrm{Kb}$ & $0,33 \mathrm{a}$ & $0 \mathrm{~b}$ & $0 \mathrm{a}$ & nt & $1,33 a$ & $6.33 \mathrm{~b}$ & $0 \mathrm{a}$ & $1.33 \mathrm{~b}$ & & $23 a$ & Oa & nt & $0 \mathrm{a}$ & nt & $0 \mathrm{a}$ & nt & $0 \mathrm{a}$ & nt & $0 \mathrm{a}$ & nt \\
\hline KKB & $0 \mathrm{a}$ & $0.66 \mathrm{~b}$ & $0 \mathrm{a}$ & $\mathrm{Oa}$ & $5.33 \mathrm{a}$ & $15,5 \mathrm{a}$ & $0.33 \mathrm{a}$ & $8 a$ & $1.66 \mathrm{a}$ & $0,5 \mathrm{a}$ & Oa & $0 \mathrm{a}$ & $2.33 \mathrm{a}$ & $1,33 \mathrm{a}$ & $0 \mathrm{a}$ & $0 \mathrm{a}$ & $0 \mathrm{a}$ & $0 \mathrm{a}$ & $0 \mathrm{a}$ & $0 \mathrm{a}$ \\
\hline KS & $0.33 a$ & $6,66 \mathrm{a}$ & $0 \mathrm{a}$ & $0 \mathrm{a}$ & $11.66 \mathrm{a}$ & $7,33 a$ & $5.00 \mathrm{a}$ & $5 \mathrm{a}$ & $4.33 \mathrm{a}$ & $\mathrm{Oa}$ & $0 \mathrm{a}$ & Oa & $1.66 \mathrm{a}$ & $0 \mathrm{a}$ & $0 \mathrm{a}$ & $0 \mathrm{a}$ & $\mathrm{Oa}$ & $\mathrm{Oa}$ & $0 \mathrm{a}$ & $0 \mathrm{a}$ \\
\hline KT & $8,00 \mathrm{a}$ & $10 \mathrm{a}$ & $0 \mathrm{a}$ & $\mathrm{Oa}$ & $1,33 a$ & $8,33 \mathrm{a}$ & $4,66 \mathrm{a}$ & $6 a$ & $14,66 \mathrm{a}$ & $11,66 a$ & $0 \mathrm{a}$ & $0 \mathrm{a}$ & $0,33 \mathrm{a}$ & $0,33 \mathrm{a}$ & $0 \mathrm{~b}$ & $0 \mathrm{a}$ & $0 \mathrm{~b}$ & Oa & $0 \mathrm{~b}$ & $\mathrm{Oa}$ \\
\hline LO & $5,66 \mathrm{a}$ & $7,66 \mathrm{a}$ & $0 \mathrm{a}$ & $0 \mathrm{~b}$ & $5,00 \mathrm{a}$ & $\mathrm{nt}$ & $4,00 \mathrm{a}$ & $1 \mathrm{~b}$ & $4,00 \mathrm{a}$ & $3.66 \mathrm{a}$ & $0 \mathrm{a}$ & $0 \mathrm{~b}$ & $0 \mathrm{a}$ & $0 \mathrm{~b}$ & $0 \mathrm{~b}$ & $0 \mathrm{~b}$ & $0 \mathrm{~b}$ & $0 \mathrm{~b}$ & $0 \mathrm{~b}$ & nt \\
\hline NDY & $0 \mathrm{~b}$ & $\mathrm{nt}$ & $0 \mathrm{~b}$ & $\mathrm{Oa}$ & $14,66 a$ & $8 \mathrm{a}$ & $2,33 \mathrm{~b}$ & $9,66 \mathrm{a}$ & $5,66 \mathrm{~b}$ & 7,33a & $0 \mathrm{~b}$ & $0 \mathrm{a}$ & $0,33 \mathrm{~b}$ & nt & $0 \mathrm{~b}$ & $0 \mathrm{a}$ & $0 \mathrm{~b}$ & $0 \mathrm{a}$ & $0 \mathrm{~b}$ & $0 \mathrm{a}$ \\
\hline NPO & $1,00 \mathrm{~b}$ & nt & $0 \mathrm{~b}$ & $35,66 a$ & $21,33 \mathrm{a}$ & $35,33 a$ & $0,33 b$ & $2,5 \mathrm{a}$ & $12,00 \mathrm{ab}$ & $19,66 \mathrm{a}$ & & nt & $1,00 \mathrm{~b}$ & $0,66 a$ & $0 \mathrm{~b}$ & $\mathrm{nt}$ & $0 \mathrm{~b}$ & nt & $0 \mathrm{~b}$ & nt \\
\hline NTP & $0,66 \mathrm{~b}$ & $3 a$ & $0 \mathrm{~b}$ & $0 b$ & $10,00 \mathrm{~b}$ & $3.5 \mathrm{a}$ & $4,33 \mathrm{~b}$ & $0,66 \mathrm{~b}$ & $30,00 \mathrm{a}$ & $0 \mathrm{~b}$ & $0 \mathrm{~b}$ & $0 \mathrm{~b}$ & $6,00 \mathrm{~b}$ & $1 b$ & $0 \mathrm{a}$ & $0 \mathrm{~b}$ & $0 \mathrm{a}$ & $0 \mathrm{~b}$ & $0 \mathrm{a}$ & $0 \mathrm{~b}$ \\
\hline OM & $0 \mathrm{~b}$ & $6,66 \mathrm{a}$ & $0 \mathrm{~b}$ & $0 \mathrm{~b}$ & 4,66b & $19 \mathrm{a}$ & $2,66 \mathrm{~b}$ & $4.66 \mathrm{~b}$ & $14,66 \mathrm{a}$ & $6.66 \mathrm{~b}$ & $0 \mathrm{~b}$ & $0 \mathrm{~b}$ & $0 \mathrm{~b}$ & $1 \mathrm{~b}$ & $0 \mathrm{a}$ & $0 \mathrm{~b}$ & $0 \mathrm{a}$ & $0 \mathrm{~b}$ & $0 \mathrm{a}$ & $0 \mathrm{~b}$ \\
\hline OZN & $4,33 \mathrm{~b}$ & $1 \mathrm{~b}$ & $0 \mathrm{~b}$ & $0 \mathrm{~b}$ & $19,00 \mathrm{a}$ & $15 \mathrm{a}$ & $2,00 \mathrm{~b}$ & $0,66 \mathrm{~b}$ & $8,00 \mathrm{~b}$ & $0,33 \mathrm{~b}$ & $0 \mathrm{~b}$ & $0 \mathrm{~b}$ & $1,33 \mathrm{~b}$ & $0 \mathrm{~b}$ & $0 \mathrm{~b}$ & $0 \mathrm{~b}$ & $0 \mathrm{~b}$ & $0 \mathrm{~b}$ & $0 \mathrm{~b}$ & $0 \mathrm{~b}$ \\
\hline SB & $0 \mathrm{~b}$ & nt & $0,33 \mathrm{~b}$ & nt & $8,33 a$ & $\mathrm{nt}$ & $1,66 \mathrm{~b}$ & nt & $2,00 \mathrm{~b}$ & nt & $0 \mathrm{~b}$ & $\mathrm{nt}$ & $0 \mathrm{~b}$ & $\mathrm{nt}$ & $0 \mathrm{~b}$ & nt & $0 \mathrm{~b}$ & $\mathrm{nt}$ & $0 \mathrm{~b}$ & nt \\
\hline SDN & Oa & 1a & $0,66 \mathrm{a}$ & $6,66 \mathrm{a}$ & $19,00 \mathrm{a}$ & $11,33 a$ & $0,33 \mathrm{a}$ & $13,33 \mathrm{a}$ & $13,00 \mathrm{a}$ & $22,33 a$ & $0 \mathrm{a}$ & $0 \mathrm{a}$ & $6,33 \mathrm{a}$ & $65 \mathrm{a}$ & $0 \mathrm{a}$ & $0 \mathrm{a}$ & $0 \mathrm{a}$ & Oa & Oa & $\mathrm{Oa}$ \\
\hline SL & $0.66 \mathrm{a}$ & $0,5 \mathrm{a}$ & $0 \mathrm{a}$ & $0 \mathrm{a}$ & $3.33 \mathrm{a}$ & $5.66 \mathrm{a}$ & $0.66 \mathrm{a}$ & $0 \mathrm{a}$ & $1.66 \mathrm{a}$ & $4.33 \mathrm{a}$ & $\mathrm{Oa}$ & $0 \mathrm{a}$ & $0 \mathrm{a}$ & $0 \mathrm{a}$ & $0 \mathrm{a}$ & $0 \mathrm{a}$ & $0 \mathrm{a}$ & $0 \mathrm{a}$ & $0 \mathrm{a}$ & $\mathrm{Oa}$ \\
\hline SPM & $9,33 \mathrm{a}$ & $9,5 \mathrm{ab}$ & $0 \mathrm{a}$ & $0 \mathrm{~b}$ & $9,66 a$ & $17,5 \mathrm{a}$ & $7,00 \mathrm{a}$ & $\mathrm{nt}$ & $3,00 \mathrm{a}$ & $1,33 \mathrm{~b}$ & $0 \mathrm{a}$ & $0 \mathrm{~b}$ & $0 \mathrm{a}$ & $4,66 \mathrm{~b}$ & $0 \mathrm{a}$ & $0 \mathrm{~b}$ & $0 \mathrm{a}$ & $0 \mathrm{~b}$ & $0 \mathrm{a}$ & $0 \mathrm{~b}$ \\
\hline SPO & $4,66 a b$ & $\mathrm{nt}$ & $0 \mathrm{~b}$ & $\mathrm{Oa}$ & $9,00 \mathrm{a}$ & $0,66 \mathrm{a}$ & $0,33 \mathrm{~b}$ & $3 a$ & $1,66 \mathrm{~b}$ & $4 a$ & $0 \mathrm{~b}$ & $0 \mathrm{a}$ & $0 \mathrm{~b}$ & $0,66 a$ & $0 \mathrm{~b}$ & $0 \mathrm{a}$ & $0 \mathrm{~b}$ & $0 \mathrm{a}$ & $0 \mathrm{~b}$ & $\mathrm{Oa}$ \\
\hline SPT & $3,66 \mathrm{ab}$ & $9 a$ & $0 \mathrm{~b}$ & $\mathrm{Oa}$ & $13,66 a$ & $12,66 a$ & $1,66 \mathrm{ab}$ & 21a & $14,00 \mathrm{a}$ & $26 a$ & $0 b$ & $0 \mathrm{a}$ & $0 \mathrm{~b}$ & $0,33 \mathrm{a}$ & $0 \mathrm{~b}$ & $0 \mathrm{a}$ & $0 \mathrm{~b}$ & $0 \mathrm{a}$ & $0 \mathrm{~b}$ & $0 \mathrm{a}$ \\
\hline STD & $2,33 b$ & $3.33 \mathrm{ab}$ & $0 \mathrm{~b}$ & $0 \mathrm{~b}$ & $9,33 \mathrm{ab}$ & $1 a b$ & $15,33 \mathrm{a}$ & $4.33 \mathrm{ab}$ & $9,33 \mathrm{ab}$ & $8 a$ & $0 \mathrm{~b}$ & $0 \mathrm{~b}$ & $0 \mathrm{~b}$ & $0 \mathrm{~b}$ & $0 \mathrm{~b}$ & $0 \mathrm{~b}$ & $0 \mathrm{~b}$ & $0 \mathrm{~b}$ & $0 \mathrm{~b}$ & $0 \mathrm{~b}$ \\
\hline YS & $0 \mathrm{~b}$ & $4 a$ & $0 \mathrm{~b}$ & $\mathrm{Oa}$ & $9,33 \mathrm{a}$ & & $6,66 a$ & $2,66 a$ & $7,66 a$ & $0,66 \mathrm{a}$ & $0 b$ & $0 \mathrm{a}$ & $0 \mathrm{~b}$ & $0 \mathrm{a}$ & $0 \mathrm{~b}$ & $0 \mathrm{a}$ & $0 \mathrm{~b}$ & $0 \mathrm{a}$ & $0 \mathrm{~b}$ & $0 \mathrm{a}$ \\
\hline $\mathrm{ZN}$ & $0 \mathrm{~b}$ & $10,33 \mathrm{a}$ & $0 \mathrm{~b}$ & $4,5 \mathrm{a}$ & $14,66 \mathrm{a}$ & $27 \mathrm{a}$ & $8,33 \mathrm{ab}$ & 0.25 & $4,33 \mathrm{ab}$ & 24,66 a & $0 \mathrm{~b}$ & $0 \mathrm{a}$ & $0,66 \mathrm{~b}$ & $3 a$ & $0 \mathrm{~b}$ & $0 \mathrm{a}$ & $0 \mathrm{~b}$ & $0 \mathrm{a}$ & $0 \mathrm{~b}$ & $0 \mathrm{a}$ \\
\hline ZSF & $9,66 \mathrm{ab}$ & $\mathrm{nt}$ & $0 \mathrm{~b}$ & $\mathrm{nt}$ & $13,66 \mathrm{a}$ & nt & $1,33 b$ & nt & $4,33 \mathrm{~b}$ & $\mathrm{nt}$ & $0 \mathrm{~b}$ & $\mathrm{nt}$ & $0,33 \mathrm{~b}$ & nt & $0 \mathrm{~b}$ & $\mathrm{nt}$ & $0 \mathrm{~b}$ & nt & $0 \mathrm{~b}$ & nt \\
\hline
\end{tabular}

NSSP = Number of shoots of Striga emerged; BI : Ipélcé ; BTo : Toécé ; FD : Diapangou ; GZR : Zam ; Kb : Kamboinsé ; KKB : Baskouré ; KS : Sapaga ; KT : Tintilou ; NDY : Dargo ; NTP: Toma ; OM : Manèga ; OZN : Zitenga ; SL : Lankoué ; SPM : Pobé-Mengao; SPO : Pibaoré ; SPT : Tita ; ZSF : Sapouy ; FK : Kouaré ; BPB : Poura ; BSG : Saria ; HB : Bama ; BTe : Tenkodogo ; FFB : Boulontou ; LO : Titao ; STD : Toénie ; YS : Séguénéga ; NP : Po ; SB : Bani ; SDN : Dori ; ZN : Nobéré 
TABLE 6. Number of Striga shoots emerged and its severity score over two years of the experiment

\begin{tabular}{|c|c|c|c|c|}
\hline \multirow[t]{2}{*}{ Ecotype of Striga } & \multicolumn{2}{|c|}{ NSSP } & \multicolumn{2}{|c|}{ SEV } \\
\hline & 2018 & 2019 & 2018 & 2019 \\
\hline BI & $3,31 b c$ & $\mathrm{Nt}$ & $1,55 \mathrm{bc}$ & $\mathrm{nt}$ \\
\hline BPB & $2,4 b c$ & $\mathrm{Nt}$ & $1,23 b c$ & $\mathrm{nt}$ \\
\hline BSG & $5,7 \mathrm{abc}$ & $\mathrm{Nt}$ & $1,43 b c$ & $\mathrm{nt}$ \\
\hline $\mathrm{BTe}$ & $8,77 \mathrm{a}$ & $5,11 \mathrm{ab}$ & $2,1 \mathrm{a}$ & $2,07 \mathrm{a}$ \\
\hline BTo & $2,07 b c$ & $\mathrm{Nt}$ & $1,7 a b c$ & $\mathrm{nt}$ \\
\hline $\mathrm{FD}$ & $3,27 b c$ & $5,24 \mathrm{ab}$ & $1,17 b c$ & $1,75 a b$ \\
\hline FFB & $1,23 b c$ & $4,88 \mathrm{ab}$ & $1,47 b c$ & $1,71 \mathrm{ab}$ \\
\hline $\mathrm{FK}$ & $2,77 b c$ & $3 \mathrm{ab}$ & $1,13 b c$ & $1,43 \mathrm{ab}$ \\
\hline GZR & $6,87 \mathrm{ab}$ & $\mathrm{Nt}$ & $1,77 \mathrm{ab}$ & $\mathrm{nt}$ \\
\hline $\mathrm{HB}$ & $2,23 b c$ & $8,42 \mathrm{ab}$ & $1,3 b c$ & $1,9 \mathrm{a}$ \\
\hline $\mathrm{Kb}$ & $0,17 \mathrm{c}$ & $3,33 \mathrm{ab}$ & $1 \mathrm{c}$ & $1,43 \mathrm{ab}$ \\
\hline KKB & $0,97 \mathrm{bc}$ & $2,86 a b$ & $1,17 b c$ & $1,5 \mathrm{ab}$ \\
\hline $\mathrm{KS}$ & $2,3 b c$ & $0,25 b$ & $1,37 b c$ & $1,25 \mathrm{ab}$ \\
\hline KT & $2,9 b c$ & $3,4 \mathrm{ab}$ & $1,07 \mathrm{bc}$ & $1,77 \mathrm{ab}$ \\
\hline LO & $1,87 b c$ & $0,4 b$ & $1,6 b c$ & $1,37 \mathrm{ab}$ \\
\hline NDY & $2,3 b c$ & $2,62 \mathrm{ab}$ & $1,5 b c$ & $1,72 \mathrm{ab}$ \\
\hline NPO & $3,57 b c$ & $10,31 \mathrm{a}$ & $1,33 b c$ & $1,86 \mathrm{ab}$ \\
\hline NTP & $5,1 b c$ & $0,48 b$ & $1,17 b c$ & $1,21 \mathrm{ab}$ \\
\hline $\mathrm{OM}$ & $2,2 b c$ & $2,68 \mathrm{ab}$ & $1,27 b c$ & $1,55 \mathrm{ab}$ \\
\hline $\mathrm{OZN}$ & $3,47 b c$ & $1,6 \mathrm{~b}$ & $1,33 b c$ & $1,43 \mathrm{ab}$ \\
\hline SB & $1,23 b c$ & $\mathrm{Nt}$ & $1,3 b c$ & $\mathrm{nt}$ \\
\hline SDN & $3,93 b c$ & $5,66 a b$ & $1,2 \mathrm{bc}$ & $1,67 \mathrm{ab}$ \\
\hline SL & $0,63 b c$ & $1,07 \mathrm{~b}$ & $1,13 b c$ & $1,45 a b$ \\
\hline SPM & $2,9 b c$ & $2,67 a b$ & $1,3 b c$ & $1,47 \mathrm{ab}$ \\
\hline SPO & $1,57 b c$ & $0,67 b$ & $1,2 b c$ & $1,4 \mathrm{v}$ \\
\hline SPT & $3,3 \mathrm{bc}$ & $5,78 \mathrm{ab}$ & $1,3 b c$ & $1,71 \mathrm{ab}$ \\
\hline STD & $3,63 b c$ & $1,45 b$ & $1,53 b c$ & $1,59 \mathrm{ab}$ \\
\hline YS & $2,37 b c$ & $0,77 b$ & $1,2 b c$ & $1,59 \mathrm{ab}$ \\
\hline $\mathrm{ZN}$ & $2,8 b c$ & $8 \mathrm{ab}$ & $1,43 b c$ & $1,93 \mathrm{a}$ \\
\hline ZSF & $2,93 b c$ & $\mathrm{Nt}$ & $1,23 b c$ & $\mathrm{nt}$ \\
\hline Means & 2,86 & 3,50 & 1,33 & 1,57 \\
\hline F-value & $2,2637 * * *$ & $2,7 * * *$ & $2,9865 * * *$ & $2,13 * *$ \\
\hline $\operatorname{Pr}(>\mathrm{F})$ & $<0,0001$ & $<0,0001$ & $<0,0001$ & 0,001 \\
\hline
\end{tabular}

$\mathrm{PSP}=$ number of Striga emerged shoots; SEV = severity of Striga attacks. means followed by the same letters are not significantly different; BI : Ipélcé; BTo : Toécé; FD : Diapangou; GZR : Zam; Kb : Kamboinsé; KKB : Baskouré; KS : Sapaga; KT : Tintilou; NDY : Dargo; NTP: Toma; OM : Manèga; OZN : Zitenga; SL : Lankoué; SPM : Pobé-Mengao; SPO : Pibaoré; SPT : Tita; ZSF : Sapouy; FK : Kouaré; BPB : Poura; BSG : Saria; HB : Bama; BTe : Tenkodogo; FFB : Boulontou; LO : Titao; STD : Toénie; YS : Séguénéga; NP : Po; SB : Bani; SDN : Dori; ZN : Nobéré 
Cluster dendrogram for solution HClus.16

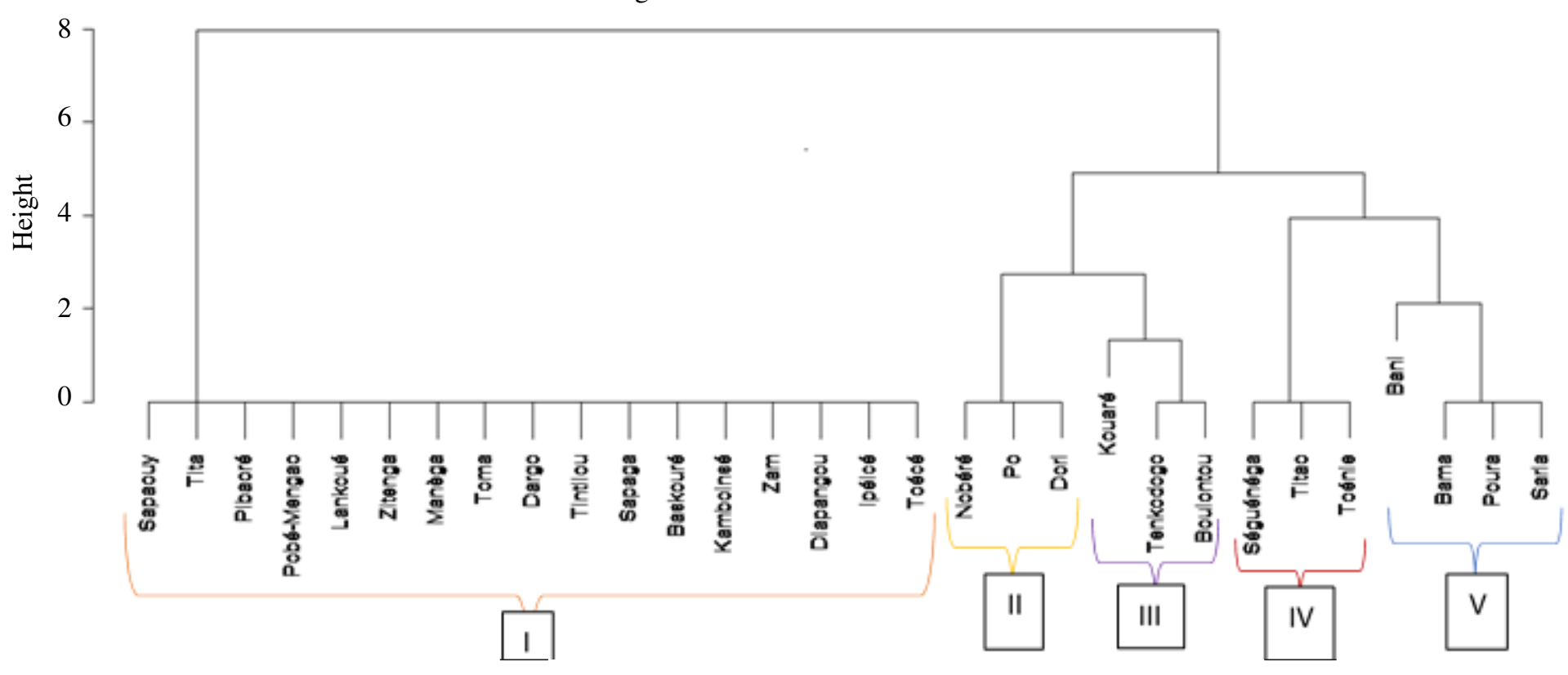

Observation number in data set Dataset Method=ward; Distance=euclidian

Figure 2. Cluster analysis of Striga gesnerioides ecotypes according to Ward's aggregation criteria based on the differential reaction of four cowpea varieties. 
TABLE 7. Responses of cowpea varieties to Striga gesnerioides ecotypes

\begin{tabular}{|c|c|c|c|c|c|c|c|c|c|c|}
\hline Variety & Komsaré & KVx404-8-1 & $\begin{array}{c}\text { Moussa } \\
\text { local }\end{array}$ & $524 \mathrm{~B}$ & Tiligre & $\begin{array}{c}\text { Gorom } \\
\text { local }\end{array}$ & Niizwe & B301 & $\begin{array}{l}\text { IT82D } \\
-849\end{array}$ & $\begin{array}{l}\text { IT93K } \\
-693-2\end{array}$ \\
\hline BI & 1 & 1 & 1 & 1 & 1 & 0 & 0 & 0 & 0 & 0 \\
\hline BPB & 1 & 1 & 1 & 0 & 1 & 0 & 0 & 0 & 0 & 0 \\
\hline BSG & 1 & 1 & 1 & 0 & 1 & 0 & 0 & 0 & 0 & 0 \\
\hline $\mathrm{BTe}$ & 1 & 1 & 1 & 1 & 1 & 1 & 1 & 0 & 0 & 0 \\
\hline BTo & 1 & 1 & 1 & 1 & 1 & 0 & 0 & 0 & 0 & 0 \\
\hline FD & 1 & 1 & 1 & 1 & 1 & 0 & 0 & 0 & 0 & 0 \\
\hline FFB & 1 & 1 & 1 & 1 & 1 & 1 & 1 & 0 & 0 & 0 \\
\hline FK & 1 & 1 & 1 & 1 & 1 & 0 & 1 & 0 & 0 & 0 \\
\hline GZR & 1 & 1 & 1 & 1 & 1 & 0 & 0 & 0 & 0 & 0 \\
\hline $\mathrm{HB}$ & 1 & 1 & 1 & 0 & 1 & 0 & 0 & 0 & 0 & 0 \\
\hline $\mathrm{Kb}$ & 1 & 1 & 1 & 1 & 1 & 0 & 0 & 0 & 0 & 0 \\
\hline KKB & 1 & 1 & 1 & 1 & 1 & 0 & 0 & 0 & 0 & 0 \\
\hline $\mathrm{KS}$ & 1 & 1 & 1 & 1 & 1 & 0 & 0 & 0 & 0 & 0 \\
\hline KT & 1 & 1 & 1 & 1 & 1 & 0 & 0 & 0 & 0 & 0 \\
\hline LO & 1 & 1 & 1 & 1 & 0 & 0 & 0 & 0 & 0 & 0 \\
\hline NDY & 1 & 1 & 1 & 1 & 1 & 0 & 0 & 0 & 0 & 0 \\
\hline NPO & 1 & 1 & 1 & 1 & 1 & 1 & 0 & 0 & 0 & 0 \\
\hline NTP & 1 & 1 & 1 & 1 & 1 & 0 & 0 & 0 & 0 & 0 \\
\hline $\mathrm{OM}$ & 1 & 1 & 1 & 1 & 1 & 0 & 0 & 0 & 0 & 0 \\
\hline $\mathrm{OZN}$ & 1 & 1 & 1 & 1 & 1 & 0 & 0 & 0 & 0 & 0 \\
\hline SB & 1 & 1 & 1 & 0 & 0 & 1 & 0 & 0 & 0 & 0 \\
\hline SDN & 1 & 1 & 1 & 1 & 1 & 1 & 0 & 0 & 0 & 0 \\
\hline SL & 1 & 1 & 1 & 1 & 1 & 0 & 0 & 0 & 0 & 0 \\
\hline SPM & 1 & 1 & 1 & 1 & 1 & 0 & 0 & 0 & 0 & 0 \\
\hline SPO & 1 & 1 & 1 & 1 & 1 & 0 & 0 & 0 & 0 & 0 \\
\hline SPT & 1 & 1 & 1 & 1 & 1 & 0 & 0 & 0 & 0 & 0 \\
\hline STD & 1 & 1 & 1 & 1 & 0 & 0 & 0 & 0 & 0 & 0 \\
\hline YS & 1 & 1 & 1 & 1 & 0 & 0 & 0 & 0 & 0 & 0 \\
\hline $\mathrm{ZN}$ & 1 & 1 & 1 & 1 & 1 & 1 & 0 & 0 & 0 & 0 \\
\hline ZSF & 1 & 1 & 1 & 1 & 1 & 0 & 0 & 0 & 0 & 0 \\
\hline
\end{tabular}

“1” presence of Striga; “0” absence of Striga; BI : Ipélcé; BTo : Toécé; FD : Diapangou; GZR : Zam; Kb : Kamboinsé; KKB : Baskouré; KS : Sapaga; KT : Tintilou; NDY : Dargo; NTP: Toma; OM : Manèga; OZN : Zitenga; SL : Lankoué; SPM : Pobé-Mengao; SPO : Pibaoré; SPT : Tita; ZSF : Sapouy; FK : Kouaré; BPB : Poura; BSG : Saria; HB : Bama; BTe : Tenkodogo; FFB : Boulontou; LO : Titao; STD : Toénie; YS : Séguénéga; NP : Po; SB : Bani; SDN : Dori; ZN : Nobéré

Table 8 illustrates the comparison of Striga gesnerioides ecotypes in Burkina Faso with races already identified based on the response of cowpea varieties. It is clear that Group I consists of the ecotypes of race SG1, Group $\mathrm{V}$ consists of the ecotypes of race SG 5 and Group III consists of the ecotypes of race SG
Kp. Based on the reaction of variety Tiligré to the ecotypes of group IV, these ecotypes could be assimilated to race SG1 or determined as a virulent group of race SG1. The distribution of ecotypes according to groups or biotypes is presented in Table 9. Figure 2 shows the spatial distribution of the different races of 
Differential and comparative screening of cowpea varieties

Striga gesnerioides throughout in Burkina Faso.

\section{DISCUSSION}

The cowpea varieties tested in these experiments revealed the presence of genetic variability among them, as regard to their responses to the different ecotypes of Striga gesnerioides (Table 5). The results of the two different screening tests revealed that cowpea varieties had differential responses depending on the origin of Striga seeds (Table 5). This different reaction allowed for the characterisation of the thirty ecotypes of Striga gesnerioides used in this study. The three susceptible varieties (Komsaré, Moussa local and KVx404-8-1), were consistently susceptible to Striga gesnerioides seeds from all the 30 localities. They induced Striga seeds germination and shoots emergence for all the 30 ecotypes of Striga seeds, indicating that Striga seeds were viable and the screening was appropriate. Therefore, the different reactions observed with other cowpea varieties (Table 7) clearly indicate the existence of intraspecific variability within the screened Striga ecotypes. Inferring the presence of different biotypes or races within Striga gesnerioides in Burkina Faso, which may be related to the geographical zones. In fact, it has been observed that each biotype prevails in a specific area as presented in Figure 2.

Among the cowpea varieties tested, B301, IT82D-849 and IT93K-693-2 were completely free from Striga gesnerioides infestation, over the two years of evaluation, and for all ecotypes of Striga (Table 5). Several other workers reported similar results showing that these three varieties possess complete resistance against the six races of Striga gesnerioides identified in West Africa (Lane et al., 1996 ; Tonessia et al., 2009; Li et al., 2009; Omoigui et al., 2012). The resistances observed in B301 and IT93K-693-2 are consistent with the findings of Tignegré et al. (2013) showed that both genotypes were resistant to the three races of Striga gesnerioides in Burkina Faso. 


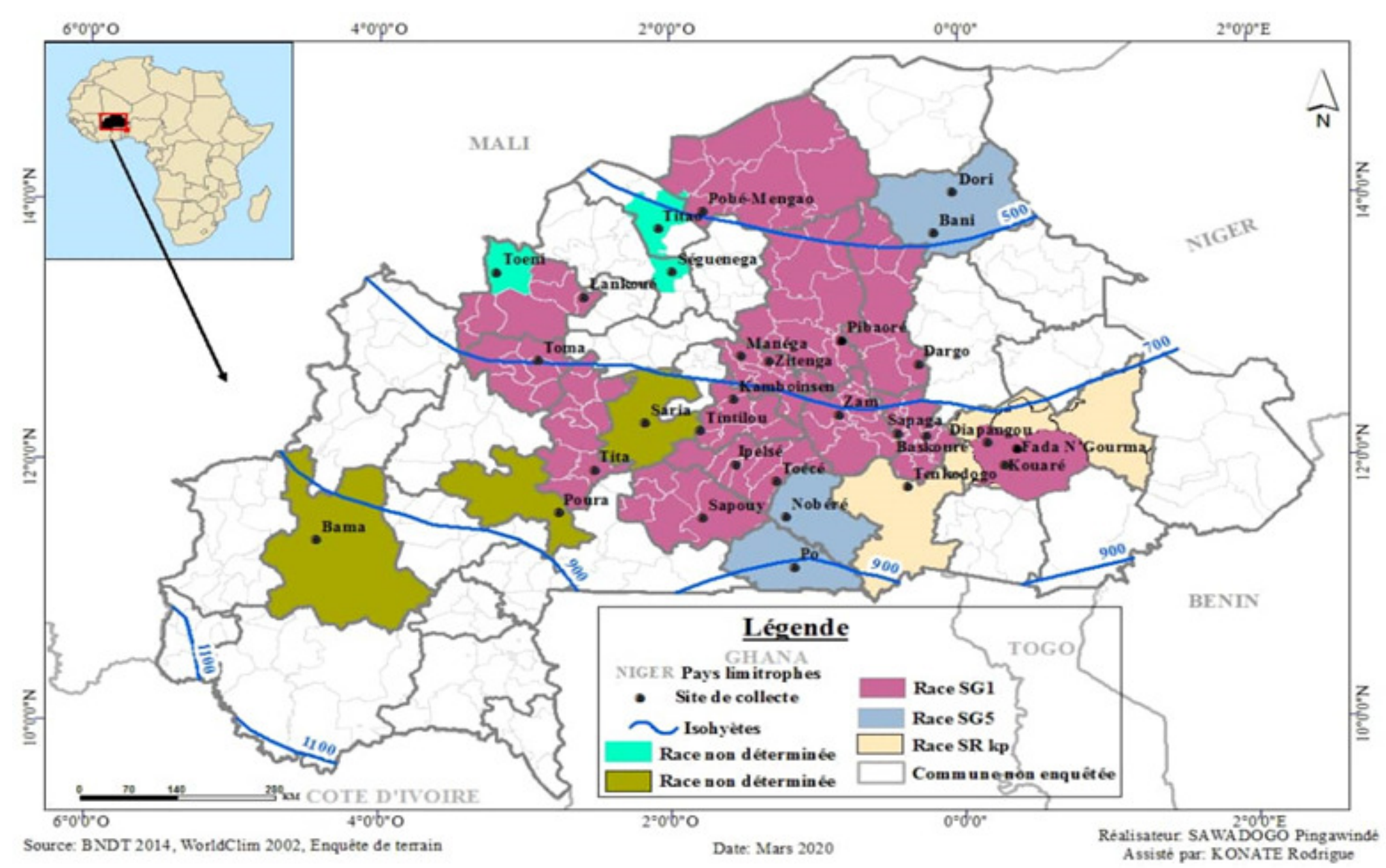

Figure 2. Distribution of the different races (biotypes) of Striga gesnerioides identified in Burkina Faso. 
Differential and comparative screening of cowpea varieties

Significant responses of cowpea varieties to Striga gesnerioides have also been reported in Niger (Salifou et al., 2017). On the other hand, screening tests conducted in different countries has revealed the presence of six intraspecific races of Striga gesnerioides in West Africa (Li et al., 2009). In addition to these six races, Tignegré et al. (2013) identified another biotype (SG Kp) that occurs in the eastern part of Burkina Faso. However, all the reported races do not occur in the same country; for example, in Burkina Faso, three races of these races (SG1, SG5 and race $\mathrm{SG}$ $\mathrm{Kp}$ ) have been reported (Ouédraogo, 2001; Tignegré et al., 2013). In addition to these three races, two biotypes from different agroecologies have been identified in the country through this study. These ecotypes were collected from agroecologies that were not fully covered by the previous intraspecific variability studies. This would justify why these Striga gesnerioides biotypes were not reported in previous studies in Burkina Faso. In addition, a clear differential reaction of cowpea genotypes to these ecotypes was observed (Table 9), implying that they are two new distinct different races of Striga gesnerioides occuring in Burkina Faso. As an illustration, variety Niizwè (IT98K-205-8) recognised as resistant to all races of Striga in Burkina Faso (Tignegré et al., 2013), was susceptible to Striga ecotypes from Tenkodogo and Boulontou. This could be explained by the phenomenon of resistance breakdown in this variety. The race of Striga occurring in this area has, therefore, developed a mechanism to overcome the resistance conferred by the variety IT98K-205-8. Though this variety still confers resistance to the other races in Burkina Faso, it is susceptible to races SG2, SG4 and SG6 (Tonessia et al., 2009; Omoigui et al., 2012). However, this study was unable to identify this biotype as one of the above races.

The ecotypes of Saria, Poura and Bama could also qualify as different biotype because of their reaction differences compaired to races SG1, SG5, SG Kp and the previous biotype. This biotype might have evolved from 
its alternative hots to the cowpea plants in locations such as Saria, Pouni and Bama. In fact, Striga infestation in the western part of the country has been recently observed due to the gradual intensification of cowpea cultivation in this area.

Co-infestation of both cowpea and the alternative host has been reported in these areas (Sawadogo et al., 2020). Cowpea infestation by Striga deriving from spontaneous vegetation has been reported by several authors (Boussim, 2002; Tonessia et al., 2009). It is important to note that Striga ecotypes from Saria, Pourra and Bama were till now not described in Burkina Faso.

Based on geographical distribution, race SG5 was predominant in the southern part of the country, race SG1 in the northern and central Burkina Faso, whereas race SG Kp was confined in the eastern part (Fig. 2). Race SG1 was the most widespread in Burkina Faso as has been earlier observed that this race was the most widespread in West Africa. This distribution is further consistent with the findings of Ouédraogo (2001) and Tignegré (2010), who worked in the areas of prevalence of race SG1. This geographical distribution has revealed that several races of Striga can occur in the same agroecology. Seed dissemination through human activities, animals or water partly explains the coinfestation of two or more races in a particular area. The co-occurrence of several Striga biotypes in the same agricultural district could explain why improved varieties for Striga resistance are observed to be susceptible to Striga in some agricultural areas of Burkina Faso.

\section{CONCLUSION}

In the present study, four cowpea varieties (Tiligré, 524B, Gorom Local, Niizwè) have displayed different responses (susceptibility or resistance) to the ecotypes of Striga gesnerioides used. Varieties Moussa Local, Komsaré and KVx404-8-1 are susceptible to all ecotypes of Striga prevailing in Burkina Faso. The reverse is true for genotypes B301, IT93K-693-2 and IT82D-849. Based on the degrees of reaction of cowpea varieties, the ecotypes of Striga used in this study are grouped into five classes, representing different races. Among these races, three are clearly identified as races SG1, SG5 and SG Kp. Two distinct new biotypes have been identified and the geographical distribution map of Striga gesnerioides in Burkina Faso established. However, the study did not allow for a clear affiliation of the newly identified races to the other races in West Africa. These results will serve to redefine the deployment of Striga resistant varieties across the country.

\section{ACKNOWLEDGEMENT}

Authors acknowledge the Institute of Environment and Agricultural Research (INERA), through its research station in Kamboinsé/Ouagadougou, for hosting and providing the necessary equipment for the implementation of this work. We are also grateful to the project Kirkhouse Trust for funding this study.

\section{REFERENCES}

Alonge, S., Lagoke, S. and Ajakaiye, C. 2005. Cowpea reactions to Striga gesnerioides, effect on growth. Crop Protection 24:565573. doi: 10.1016/j.cropro.2004.08.014.

Botanga, C. and Timko, M. 2006. Phenetic relationships among different races of Striga gesnerioides (Willd.) Vatke from West Africa. Genome 49(11):1351-1365. doi: 10.1139/G06-086.

Boussim, I. 2002. Les Phanérogames parasites du Burkina Faso/ : inventaire, taxonomie, écologie et quelques aspects de leur biologie. Cas particulier des Loranthaceae parasites du karité. Thèse de doctorat., Université de Ouagadougou. 285pp.

Csurhes, S., Markula, A. and Zhou, Y. 2013. Invasive plant risk assessment: Witchweeds 
Striga species. Queensland Government; $17 \mathrm{pp}$.

Husson, O., Michellon, R., Charpentier, H., Razanamparany, C., Moussa, N., Naudin, K., Razafintsalama, H., Rakotoarinivo, C., Andrianaivo, A., Rakotondramanana, P. and Seguy, L. 2008. Le contrôle du Striga par les systèmes SCV (Semis direct sur Couverture Végétale permanente), Manuel pratique du semis direct à Madagascar. $20 \mathrm{pp}$.

Kamara, A., Chikoye, D., Ekeleme, F., Omoigui, L.O. and Dugje, I.Y. 2008. Field performance of improved cowpea varieties under conditions of natural infestation by the parasitic weed Striga gesnerioides. International Journalof Pest Management 54(3):189-195. doi:10.1080/0967087080 1930260 .

Lane, J., Moore, T.H.M., Child, D.V. and Cardwell, K.F. 1996. Characterization of virulence and geographic distribution of Striga gesnerioides in West Africa. Plant Disease 80(3):299-301.

Lane, J., Moore, T.H.M., Child, D.V. et Bailey, J.A. 1997. Variation in virulence of Striga gesnerioides on cowpea new sources of crop resistance. Diseases and Parasitic Weeds 84(2):225-230.

Li, J., Lis, K. and Timko, M. 2009. Molecular genetics of race-specific resistance of cowpea to Striga gesnerioides ( Willd .). Pest Manage Science 65:520-527. doi: 10.1002/ps. 1722.

Ohlson, E. and Timko, M. 2020. Race structure of cowpea witchweed (Striga gesnerioides) in West Africa and its implications for Striga resistance breeding of cowpea. Weed Science 68(2):125-133. doi: 10.1017/wsc.2020.3.

Omoigui, LO. Kamara, A. Y., Ishiyaku, M. F. and Boukar, O. 2012. Comparative responses of cowpea breeding lines to Striga and Alectra in the dry savanna of northeast Nigeria. African Journal of Agricultural Research 7(5):747-754. doi: 10.5897/AJAR11.1341.
Ouédraogo, J.T., Ouédraogo, M., Gowda, S.B. and Timko, M.P. 2012. Development of sequence characterized amplified region (SCAR ) markers linked to race-specific resistance to Striga gesnerioides in cowpea ( Vigna unguiculata L .). African Journal of Biotechnology 11(62):12555-12562. doi: 10.5897/AJB12.805.

Ouédraogo, J.T. 2001. Construction d'une carte de liaison génétique du niébé (Vigna unguiculata (L.) Walp.) et identification de marqueurs AFLP liés aux gènes de résistances au Striga gesnerioides (WILLD.) Vatke. Thèse de doctorat, Université de Laval, Québec. 174pp.

Ouédraogo, O. 1995. Contribution à l'étude de quelques phanérogames parasites des cultures au Burkina Faso/ : incidence, biologie et méthodes de lutte. Paris 6. 95pp. Ouédraogo, J.T., Maheshwari, V·, Berner, K. D., Pierre, St. A.C., Belzile, F. et Timko, P.M. 2001. Identification of AFLP markers linked to resistance of cowpea (Vigna unguiculata L.) to parasitism by Striga gesnerioides. Theoretical and Applied Genetic 102:1029-1036.

Parker, C. 2009. Observations on the current status of Orobanche and Striga problems worldwide. Pest Manage Science 65:453459. doi: 10.1002/ps.1713.

Salifou, M., Tignegre, J.B.L.S., Tongoona, P., Offei, S., Ofori, K. and Danquah, E. 2017. Differential responses of 15 cowpea genotypes to three Striga hot spots in Niger. International Journal of Biology and Chemical Sciences 11(4):1413-1423. doi:http:// dx.doi.org/10.4314/ijbcs.v11i4.2. Sawadogo, P., Batieno, T.B.J., Dieni, Z., Sawadogo, N., Ouédraogo, J.T. and Sawadogo, M. 2020. Geographical distribution and alternate hosts of Striga gesnerioides (Willd.) Vatke in Burkina Faso. Journal of Applied Biosciences 145: 14955-14964. doi: 10.35759/jabs.v145.10.

Singh, B.B. and Emechebe, A.M. 1997. Advances in research on cowpea Striga and Alectra. In: Singh, B.B., Mohan, R., 
Dashiell, K.E. and Jackai, L.E.N. (Eds.). Tignegré, J., Ouédraogo, T.J, Melis, R, Advances in Cowpea Research. Copublication of International Institute of Tropical Agriculture (UTA) and Japan International Research Center for Agricultural Sciences (JIRCAS). UTA, Ibadan, Nigeria. pp. 215-224.

Tignegré, J. 2010. Genetic study of cowpea (Vigna unguiculata (L.) Walp.) resistance to Striga gesnerioides (Willd.) Vatke in Burkina Faso. PhD thesis, University of KwaZulu-Natal Republic of South Africa, 170pp. Tongoona, P., Sibiya, J., Makanda, I and Drabo, I. 2013. Identification of new sources of resistance to Striga gesnerioides in cowpea germplasm. Plant Breeding 132: 330-336. doi: 10.1111/pbr. 12055.

Tonessia, C., Wade, M., Cissé, N. et Aké, S. 2009. Caractérisation de Striga gesnerioides (Willd) Vatke du Sénégal/ : réactions de plusieurs cultivars de niébé (Vigna unguiculata ( L.) Walp). Journal of Applied Biosciences 24:1462-1476. 